\title{
FEDERAL RULE 16: \\ A LOOK AT THE THEORY AND \\ PRACTICE OF RULEMAKING
}

\section{David L. Shapiro $\dagger$}

With characteristic skepticism, Richard Posner dismissed the one hundredth anniversary of the Harvard Law Review with a wave of his hand: "The reason the Harvard Law Review is 100 years old is that it was started 100 years ago; the law reviews of all the major law schools are still being published, and if they had been started 100 years ago they too would be 100 years old."1 Since the Federal Rules of Civil Procedure have arrived at only their fiftieth birthday, is that fact at most half as significant as the centennial of a distinguished journal? Can we say only that any set of rules promulgated fifty years ago would also be celebrating its demicentennial this year?

Not in my opinion. The Federal Rules have not just survived; they have influenced procedural thinking in every court in this land (and in some other lands), and indeed have become part of the consciousness of lawyers, judges, and scholars who worry about and live with issues of judicial procedure. The fact that on the Rules' fiftieth birthday we are engaged in a critical reexamination of some of the underlying purposes of the Rules, and of the rulemakers, in no way diminishes their stature or their importance.

But this birthday party is, quite appropriately, not just an occasion for celebration. It is a fitting time to talk about the role of procedural rules, and about whether the rulemakers of 1938 have set us on a course that needs to be modified, or substantially recharted, to take account of current conditions and attitudes.

My own inclination, when confronted with such a cosmic question, is to try to particularize it by looking at an important instance of the problem - to see whether light from one corner can help to illuminate the whole room. And so, when asked to participate in this discussion of the rulemaking process, I thought I could most usefully contribute to it by doing just that, by testing some of the rulemakers'

† William Nelson Cromwell Professor of Law, Harvard University (on leave); Deputy Solicitor General, United States Department of Justice. The views expressed are, of course, my own.

1 Posner, The Decline of Law as an Autonomous Discipline: 1962-1987, 100 HaRv. L. REv. 761, 761 (1987). 
objectives, and the critiques of those objectives, against the history and fortunes of a single rule.

The rule I have chosen for this exercise is Rule $16,{ }^{2}$ a rule that

2 FED. R. CIv. P. 16, as originally adopted in 1938, provided:

PRE-TRIAL PROCEDURE-FORMULATING ISSUES

In any action, the court may in its discretion direct the attorneys for the parties to appear before it for a conference to consider

(1) The simplification of the issues;

(2) The necessity or desirability of amendments to the pleadings;

(3) The possibility of obtaining admissions of fact and of documents which will avoid unnecessary proof;

(4) The limitation of the number of expert witnesses:

(5) The advisability of a preliminary reference of issues to a master for findings to be used as evidence when the trial is to be by jury;

(6) Such other matters as may aid in the disposition of the action.

The court shall make an order which recites the action taken at the conference, the amendments allowed to the pleadings, and the agreements made by the parties as to any of the matters considered, and which limits the issues for trial to those not disposed of by admissions or agreements of counsel; and such order when entered controls the subsequent course of the action, unless modified at the trial to prevent manifest injustice. The court in its discretion may establish by rule a pre-trial calendar on which actions may be placed for consideration as above provided and may either confine the calendar to jury actions or to non-jury actions or extend it to all actions.

The rule was amended in 1983 (and in 1987 for gender neutrality) and now provides:

Pretrial. Conferences; Scheduling; Management

(a) Pretrial Conferences; Objectives. In any action, the court may in its discretion direct the attorneys for the parties and any unrepresented parties to appear before it for a conference or conferences before trial for such purposes as

(1) expediting the disposition of the action;

(2) establishing early and continuing control so that the case will not be protracted because of lack of management;

(3) discouraging wasteful pretrial activities;

(4) improving the quality of the trial through more thorough preparation, and;

(5) facilitating the settlement of the case.

(b) Scheduling and Planning. Except in categories of actions exempted by district court rule as inappropriate, the judge, or a magistrate when authorized by district court rule, shall, after consulting with the attorneys for the parties and any unrepresented parties, by a scheduling order that limits the time

(1) to join other parties and to amend the pleadings;

(2) to file and hear motions; and

(3) to complete discovery.

The scheduling order also may include

(4) the date or dates for conferences before trial, a final pretrial conference, and trial; and

(5) any other matters appropriate in the circumstances of the case.

The order shall issue as soon as practicable but in no event more than 120 days after filing of the complaint. A schedule shall not be modified except by leave of the judge or a magistrate when authorized by district court rule upon a showing of good cause. 
was innovative when it was drafted and that has been on center stage in the continuing debate about the role of the judge in the pretrial stages of litigation. What were the purposes (and assumptions) that moved the

(c) Subjects to Be Discussed at Pretrial Conferences. The participants at any conference under this rule may consider and take action with respect to

(1) the formulation and simplification of the issues, including the elimination of frivolous claims or defenses;

(2) the necessity or desirability of amendments to the pleadings;

(3) the possibility of obtaining admissions of fact and of documents which will avoid unnecessary proof, stipulations regarding the authenticity of documents, and advance rulings from the court on the admissibility of evidence;

(4) the avoidance of unnecessary proof and of cumulative evidence;

(5) the identification of witnesses and documents, the need and schedule for filing and exchanging pretrial briefs, and the date or dates for further conferences and for trial;

(6) the advisability of referring matters to a magistrate or master;

(7) the possibility of settlement or the use of extrajudicial procedures to resolve the dispute;

(8) the form and substance of the pretrial order;

(9) the disposition of pending motions;

(10) the need for adopting special procedures for managing potentially difficult or protracted actions that may involve complex issues, multiple parties, difficult legal questions, or unusual proof problems; and

(11) such other matters as may aid in the disposition of the action.

At least one of the attorneys for each party participating in any conference before trial shall have authority to enter into stipulation and to make admissions regarding all matters that the participants may reasonably anticipate may be discussed.

(d) Final Pretrial Conference. Any final pretrial conference shall be held as close to the time of trial as reasonable under the circumstances. The participants at any such conference shall formulate a plan for trial, including a program for facilitating the admission of evidence. The conference shall be attended by at least one of the attorneys who will conduct the trial for each of the parties and by any unrepresented parties.

(e) Pretrial Orders. After any conference held pursuant to this rule, an order shall be entered reciting the action taken. This order shall control the subsequent course of the action unless modified by a subsequent order. The order following a final pretrial conference shall be modified only to prevent manifest injustice.

(f) SANCTIONS. If a party or party's attorney fails to obey a scheduling or pretrial order, or if no appearance is made on behalf of a party at a scheduling or pretrial conference, or if a party or party's attorney is substantially unprepared to participate in the conference, or if a party or party's attorney fails to participate in good faith, the judge, upon motion or the judge's own initiative, may make such orders with regard thereto as are just, and among others any of the orders provided in Rule 37(b)(2)(B), (C), (D). In lieu of or in addition to any other sanction, the judge shall require the party or the attorney representing the party or both to pay the reasonable expenses incurred because of any noncompliance with this rule, including attorney's fees, unless the judge finds that the noncompliance was substantially justified or that other circumstances make an award of expenses unjust. 
rulemakers fifty years ago? How did those forces work themselves out as the Rule was originally drafted? In the next 45 years, before the Rule was amended for the first time, were the rulemakers' purposes implemented? Their hopes borne out? Did the amendment of the Rule in 1983 reflect a change in the prevailing view of the purposes to be served by procedural rules? If so, are we on the right course at last, or is the process simply one of continual effort to correct the excesses of our predecessors?

These are large questions even in the context of one small rule. But even if our reach exceeds our grasp, we can, I think, take pleasure in the attempt.

\section{The 1930s Revisited}

\section{A. Some General Observations}

Although lawyers and judges do it all the time, it is not easy to talk about the "purposes" of a group of people. To some extent, of course, individuals share a common purpose when they act together. But it is just as true that, unless the speech were written for them, no two members of the group would give the same account, to himself or others, of why it is acting. Of course, the articulated goals of the leaders of the group are likely, with good reason, to receive the greatest weight in any analysis, but leaders too may differ among themselves, and may have goals they are unwilling to elaborate on in public.

Nevertheless, the published (and to a significant extent the unpublished) history of the federal rules, ${ }^{3}$ and the common sense of the situation the rulemakers were in, justify certain conclusions about what they thought they were up to. Indeed, I very much doubt that there would be significant disagreement about the major goals they were seeking to achieve, or the assumptions that underlay their actions. Three notions, in particular, set the theme for this discussion.

First, the rulemakers plainly thought, and expected, that the content of the rules they were writing would have an impact on the way the federal courts conducted their business; they wanted to use the opportunity to restructure civil procedure in significant ways. ${ }^{4}$ If they had

${ }^{3}$ For a full discussion and analysis of the history of the Enabling Act of 1934, 48 Stat. 1064 (codified at 28 U.S.C. $\$ 2072$ ), of earlier efforts at reform, and of the work of the first Advisory Committee, see Burbank, The Rules Enabling Act of 1934, 130 U. PA. L. Rev. 1015 (1982).

- See P. Bator, D. Meltzer, P. Mishkin \& D. Shapiro, Hart \& WechsLer's The Federal Courts and The Federal System 759 (3d ed. 1988) [hereinafter HART \& WECHSLER]; Sunderland, The New Federal Rules, 45 W. VA. L.Q. 5 (1938). 
simply wanted to clear away the debris and confusion resulting from a welter of existing practices, and felt that an effort to draft specific rules was a waste of valuable time, they would probably have come up with a variant of the present rule 1-say, "Courts shall conduct their affairs so as to secure the just, speedy, and inexpensive determination of every action"-and let it go at that. Instead, they went on for 100 or so additional pages, in an effort to create a system that would do a better job of fairly and effectively resolving disputes.

Is this first point trivial, or at best too obvious to be worth noting? Not, I think, when it is remembered that the decades leading up to the promulgation of the rules had witnessed the rise of the realist movement, which stressed among other things the indeterminacy of rules, and that the Reporter for the Rules Committee was Charles Clark, himself an academic not unsympathetic to the realist thesis. ${ }^{5}$ True, the realist criticism of the received wisdom was not so simplistic as to reject rulemaking as a worthwhile exercise-witness the dedicated efforts of Karl Llewellyn to rethink and recodify commercial law-yet Clark must occasionally have wondered whether the rulemaking effort was the best way to spend his scholarly time. ${ }^{6}$ In any event, he bit the bullet, and to my knowledge, no one debating the proposed rules suggested that the judges would do more or less what they wanted no matter what the rulemakers put on paper.

A second, and often articulated, purpose of the Rules was to achieve a higher degree of uniformity in federal practice. ${ }^{7}$ To some extent, the promulgation of the Rules could not fail to achieve this goal, because the Rules were being written against the background of the

B Of special interest is Clark's criticism, from a realist perspective, of the thesis of his fellow realist, Karl Llewellyn, as presented in Llewellyn's great work, K. LLEWELlyn, The Common Law Tradition: Deciding Appeals (1960). See Clark \& Trubek, The Creative Role of the Judge: Restraint and Freedom in the Common Law Tradition, 71 YALE L.J. 255 (1961); see also Llewellyn, Some Realism About Realism-Responding to Dean Pound, 44 HARv. L. REv. 1222, 1226 n.18 (1931) (listing Clark as one of those "recognized as figures of central stimulus in the new ferment").

- For insight into Llewellyn's role in the development of the Uniform Commercial Code, see Wiseman, The Limits of Vision: Karl Llewellyn and the Merchant Rules, 100 HaRv. L. REv. 465 (1987). For discussion of the impact of the realist movement on the Federal Rules of Civil Procedure, see, e.g., Note, Plausible Pleadings: Developing Standards for Rule 11 Sanctions, $100 \mathrm{HARV}$. L. Rev. 630, 645-47 (1987).

${ }^{7}$ See HarT \& WEChSLER, supra note 4, at 759-65; Subrin, Federal Rules, Local Rules, and State Rules: Uniformity, Divergence, and Emerging Procedural Patterns, 137 U. PA. L. REv. 1999, 2002-06 (1989). While there is no doubt of the importance attached to the development of rules of nationwide application in the federal courts, there was some question, at least at the outset, about how comprehensive these rules should be. See, e.g., Letter from Edson Sunderland to E.J. Dimock (Apr. 2, 1935) [hereinafter Sunderland Letter] (on file with the University of Pennsylvania Law Review). 
Conformity Act. ${ }^{8}$ Since the beginning of the Republic, that act and its predecessors had required federal courts in most civil matters to conform to the procedures of the states in which they sat, ${ }^{9}$ but that requirement had not resulted in uniformity even between federal and state courts within a single state; federal courts had their own procedures in equity, ${ }^{10}$ for example, and had inevitably developed, and on occasion insisted upon, their own ways of doing things in other civil matters as well. ${ }^{11}$ Thus while the replacement of the Conformity Act with a single set of federal practices would reduce the similarity between state and federal practices in the same state, it could not eliminate a uniformity that did not exist at the time, and was bound to increase the similarity of the ways in which federal courts in different states conducted their business.

The hope of the rulemakers, I believe, was a good deal more ambitious. They wanted lawyers who went into any federal court (and a growing number of lawyers had practices that focused on the federal courts in a number of states, rather than on federal and state courts within a single state) to know what to expect and not to have to undergo an initiation period or to rely heavily on the wisdom of local practitioners. They wanted to eliminate petty haggling over pointless distinctions among types of cases, and to treat as many cases as possible under the same general rubric. ${ }^{12}$ And they were sufficiently imbued with their mission to hope that their rules would set a model that the

8 Act of June 1, 1872, ch. 255, 17 Stat. 196.

${ }^{9}$ Id. at 197. The predecessors include the Process Act of Sept. 29, 1789, ch. 21, 1 Stat. 93, and the Process Act of May 19, 1828, ch. 68, 4 Stat. 278.

10 See HART \& WECHSLER, supra note 4, at 750-52 (discussing the Act of May 8,1792 , ch. $36, \S 2,1$ Stat. 275,276 ).

11 See id. at 752-53 (admiralty); id. at 753-54 (bankruptcy); id. at 758-59 (exceptions to Conformity Act arose for cases where other federal procedural statutes spoke specifically, where no "like causes" were triable in state courts, and where the question was jurisdictional; "[f]inally, even when the Act plainly applied, its terms required the federal courts to conform to state procedure only 'as near as may be" ").

12 I do not suggest that nationwide uniformity was an all-embracing purpose, or that the rulemakers were never willing to recognize appropriate distinctions among types of cases. On the first of these points, for example, Edson Sunderland wrote early in the process that many matters might not be covered in the new rules and in those matters the procedure of the state in which the federal court sat might continue to govern. See Sunderland Letter, supra note 7. Moreover, the Rules as adopted specifically left certain matters to be governed by the rule of the forum state. See, e.g., FED. R. Crv. P. 17(b), 62(f), 64, 69(a). On the second point, distinctions were recognized, for example, between the general pleading rules and the appropriate pleading requirements for fraud and for malice, see FED. R. Grv. P. 9(b), between actions tried with or without a jury, see FED. R. Crv. P. 41(b), and between default judgments in actions for a sum certain or readily calculable and actions for less definite relief, see FED. R. CIV. P. 55(b). But the rules as adopted were fairly comprehensive, and distinctions among types of cases were infrequently drawn. 
states themselves would want to follow. ${ }^{13}$

Third, the rulemakers wanted to escape the rigidities and technicalities that had attended the development of procedural codes in so many states. ${ }^{14}$ For them, the elaborate rules of pleading, the prissy limitations on joinder, amendment, variance, and discovery were all toys for the playing of elaborate and expensive parlor games by lawyers-obstacles to achieving a just and informed adjudication of the merits of an entire controversy.

The key, then, was an increase in flexibility. Judges were not, of course, to be given free rein to impose requirements regarded as obstacles to effective adjudication; ${ }^{15}$ but they were to have broad discretion to deal fairly with the case at hand and they were to be liberated from limitations that prevented a case from being decided in all of its aspects, with the best possible preparation and information possessed by the parties and available to the trier of fact. Thus the rulemakers, while willing to innovate when nothing in existing practices suited their purposes, looked favorably on the traditions of courts of equity, and askance at the more confined approach of courts of common law. ${ }^{16}$

A few comments are in order about this enumeration of the rulemakers' three purposes. Perhaps most notably, it does not purport to exhaust the shared intentions and understandings of the rulemakers, or even more clearly, the individual goals of any of the leading figures. To touch on a few other points, I think the rulemakers shared a general endorsement of the adversary system and of party control of litigation, but wanted to temper it by reducing the opportunities for surprise and concealment; ${ }^{17}$ they wanted to increase the ways in which cases could be resolved on the merits without trial while at the same time

13 See Subrin, supra note 7, at 2006; Sunderland, The Grant of Rule-Making Power to the Supreme Court of the United States, 32 Mich. L. REv. 1116, 1128-29 (1934).

14 The story is fully and convincingly told in Subrin, How Equity Conquered Common Law: The Federal Rules of Civil Procedure in Historical Perspective, $135 \mathrm{U}$. PA. L. Rev. 909 (1987). See also Sunderland, supra note 4, at 6-7 (noting the increase in "the discretionary power of district judges"); $i d$. at 30 ("The purpose . . . is to eliminate technical matters."); Sunderland Letter, supra note 7 , at 2 (suggesting "a greatly enlarged judicial discretion in dealing with all procedural questions").

${ }_{10}$ See, e.g., FED. R. Crv. P. 7(c), 8(e)(2), 15(b), 46. Clark).

16 See, e.g., Subrin, supra note 14, at 961-73 (discussing the views of Charles

${ }_{17}$ See FED. R. Grv. P. 26-37 (discovery); Sunderland, supra note 4, at 22; Sunderland, The Principles Underlying the New Federal Rules of Civil Procedure 2 (undated, unpublished manuscript) (Edson R. Sunderland Papers, Michigan Historical Collections, Bentley Historical Library, University of Michigan) (on file with the University of Pennsylvania Law Review) ("There should be adequate machinery for practically unlimited pre-trial discovery."). 
cutting down on the skirmishes over the adequacy of pleadings; ${ }^{18}$ and they wanted matters that were truly preliminary to, and generally separate from, the merits to be litigated early or not at all. ${ }^{19}$ But these various goals were, I think, derived from, and to some extent embraced within, the three major goals that I have stressed.

At the same time, none of these objectives has been without its critics, and some of those critics are especially vocal today. As already noted, those who believe in the essential indeterminacy of legal rules-some realists in the 1930 s and some present-day members of the Critical Legal Studies Movement ${ }^{20}$-might question the wisdom of an elaborate effort to frame rules for judges to follow, might argue that rules simply mask the tendency of judges to do what they choose and do not effectively constrain them.

As for the effort to achieve uniformity, inter-district uniformity was viewed by some critics of the 1930 s as essentially unattainable, and the goal of uniformity across case categories has recently come under attack from some eloquent critics on the ground that it too readily embraces a "trans-substantive" view of civil procedure. ${ }^{21}$ In the eyes of the present-day critics, the effort to achieve uniformity, to the extent that it

18 See, e.g., FED. R. Crv. P. 12(b) ("If a pleading sets forth a claim for relief to which the adverse party is not required to serve a responsive pleading, the adverse party may assert at the trial any defense in law or fact to that claim for relief."); FED. R. Civ. P. 56 (summary judgment); Sunderland, supra note 17, at 1 ("Rules should be so drawn as to offer the fewest opportunities for technical errors.").

19 See, e.g., FED. R. Grv. P. 12(g) (consolidation of defenses in motion); FED. R. Crv. P. 12(h) (waiver or preservation of certain defenses).

${ }^{20}$ For discussion and citations of the leading advocates of indeterminacy among the legal realists of the early twentieth century and the critical legal scholars of more recent years, see E. Purcell, The Crisis of Democratic Theory 74-94 (1973); Gordon, Critical Legal Histories, 36 StaN. L. REv. 57, 114-16 (1984); Note, 'Round and 'Round the Bramble Bush: From Legal Realism to Critical Legal Scholarship, 95 HaRv. L. Rev. 1669, 1670-74, 1679-82 (1982).

Traditional theories of statutory interpretation have recently been assaulted from another direction: that of public choice theory. For discussion and criticism of the efforts of public choice scholars to undermine generally accepted notions of a coherent legislative purpose, see Farber \& Frickey, The Jurisprudence of Public Choice, 65 TEX. L. REv. 873 (1987); see also Eskridge, Public Values in Statutory Interpretation, 137 U. PA. L. REV. 1007 (1989).

${ }_{21}$ For discussion of the criticism by Senator Thomas Walsh and the lawyer Connor $H$ all in the 1930s, see Subrin, supra note 7, at 2007-11. More recently, questions about the wisdom and desirability of trans-substantive rules have been raised in a variety of ways by a number of commentators. See, e.g., Cover, For James Wm. Moore: Some Reflections on a Reading of the Rules, 84 YALE L.J. 718 (1975); Resnik, Failing Faith: Adjudicatory Procedure in Decline, 53 U. CHI. L. REv. 494, 526-27, 54748 (1986); Rosenberg, The Federal Civil Rules After Half a Century, 36 ME. L. REv. 243 (1984); Subrin, supra note 14, at 991. See generally AMERICAN LAw INSTITUTE, Study on "Paths-to a 'Better Way': Litigation, Alternatives, and ACcomMODATION" 97-101 (Background Paper Jul. 1988) [hereinafter ALI STUDY] (noting situations where uniformity fails). 
fails adequately to draw relevant distinctions among types of cases, and to respect the inevitably substantive impact of all procedural rules, is a mistaken effort (often fostered by academics) to create procedure as a conceptually and operationally separate sphere of judicial and rulemaking activity.

Such critics may well approve of the rulemakers' efforts to reduce disparity from judge to judge and from court to court. But the drive for uniformity also embraced some effort to treat cases as at least presumptively alike rather than to encourage the parties to take up time fighting over what kind of case they were dealing with. Thus the rulemakers decided that a general "statement of the claim showing that the pleader is entitled to relief" was sufficient in virtually all cases, ${ }^{22}$ and that unlimited pretrial discovery, at least with respect to interrogatories and depositions, was the norm from which an aggrieved party would have to seek judicial protection. ${ }^{23}$

With respect to the desire for flexibility and discretion, some critics of the rulemakers were from the outset distressed by the "anything goes" attitude of the Rules, and worried about the shapeless and uncontainable quality that litigation might assume when they were implemented. ${ }^{24}$ That concern is far from dissipated, and has been most recently and forcefully expressed by Stephen Subrin. ${ }^{25}$ Equity, he urges, was created as a gloss on the law; discretion to depart from a norm is one thing; discretion standing alone, with nothing to measure it against, is a different, more dangerous, other thing.

One final comment: You may have noticed in this catalogue of the forces that motivated the rulemakers, some inconsistency between the second and third-between the goal of uniformity and the goal of flexibility. ${ }^{26}$ How can variations from judge to judge, and from court to

22 See FED. R. Civ. P. 8(a)(2). But of. FED. R. Grv. P. 9(b) ("circumstances constituting fraud or mistake shall be stated with particularity").

${ }^{23}$ See FED. R. CIV. P. 26-37. As originally adopted, these Rules contemplated that, except for physical examinations and the production of documents, discovery would be carried on by the parties without involvement of the court, until and unless one of the parties sought court assistance or protection. In 1970, this approach was extended to the production of documents. See Advisory Committee's Explanatory Statement Concerning Amendments of the Discovery Rules (1970 Amendments).

24 As noted by Subrin, supra note 14 , at 992 , one of the strongest opponents of modern pleading reform, and a person with whom "Clark disputed for decades" was O.L. McCaskill. For examples of McCaskill's views, see McCaskill, The Modern Philosophy of Pleading: A Dialogue Outside the Shades, 38 A.B.A. J. 123 (1952); McCaskill, Actions and Causes of Action, 34 YALE L.J. 614, 617-21 (1925).

25 See Subrin, supra note 14.

${ }^{28}$ There may also be some inconsistency between the first and third goals-between the goal of constructing a procedural system that has content and direction and the goal of vesting judges with broad flexibility to do what seems just in the circumstances. (Of course, one may think that the only sensible direction is towards 
court, be kept within livable bounds if judges have discretion to deal with cases on an ad hoc basis? And isn't the difficulty compounded by the authority, explicitly delegated to district courts in the new rules, to make local rules "not inconsistent" with the general rules?27 Many kinds of fruit and cereal are consistent with a general requirement that one must have fruit and cereal for breakfast. And if each district court may choose what kind of fruit and what kind of cereal it prefers, an appellate court cannot even try to maintain some semblance of uniformity within its own circuit by setting limits to discretion. To dine on oats and avocados in the Eastern District of Pennsylvania, and on soybeans and rhubarb in the Western District, is a long way from uniformity.

Of course, to the extent that the desire for uniformity is undermined by notions of flexibility and discretion, the critique of the transsubstantive approach is undermined too. ${ }^{28}$ Yet there remains the oftexpressed concern that the cause of justice is not advanced by uncontrolled judicial power.

The picture that emerges of the rulemakers' goals and of the critics of those goals, is not a simple one. But it is a starting point for a look at the evolution and development of rule 16.

\section{B. The Drafting of Rule 16}

The provision authorizing pretrial conferences grew out of thenexisting practices in England and in a few American courts. ${ }^{29}$ The missionary work was done primarily by Edson Sunderland, a leading academic advocate of procedural reform, a member of the original Advisory Committee, and an important figure in the development of the original Rules; his enthusiasm was shared by Charles Clark and by other members of the Advisory Committee.

Sunderland's main goal, as reflected in the final version of the Rule, was to encourage (but not require) judges to participate in sharpening and simplifying the issues of law and fact to be litigated at the trial. The shortcoming of most procedural systems, in his view, was that too much reliance was placed on the pleadings to achieve this objective and not enough either on the exchange of information or on

greater flexibility.)

${ }^{27}$ FED. R. Giv. P. 83; see Subrin, supra note 7, at 2012 (Rule 83 is a "crack in the wall of uniformity [that] has become a gaping hole").

${ }^{28}$ See Burbank, The Costs of Complexity, (Book Review), 85 Mich. L. Rev. $1463,1469-70,1474$ (1987).

${ }^{29}$ See Sunderland, The Theory and Practice of Pre-Trial Procedure, $36 \mathrm{MrcH}$.

L. REv. 215, 219-26 (1937). 
informal processes of discussion and negotiation. ${ }^{30}$ Settlement of the case, or some other disposition without trial, might result from these processes, but did not constitute their primary purpose.

Debates over the various drafts of the Rules underscored what the rulemakers had in mind. An early draft of what later became Rule 16, for example, said that on the request of either party or on the court's own initiative, a hearing would be held, after which an order might be issued for the purpose of narrowing and sharpening the issues. ${ }^{31}$ At a Committee meeting in October 1935, Chairman Mitchell ${ }^{32}$ objected that trial judges should not only have discretion about what should be done at the conference, they should also have discretion as to whether one should be held at all. ${ }^{33}$ This view was adopted in later revisions of the draft. Indeed, the final version of the Rule did not require a trial judge to do anything except to approve an order summarizing the results of the conference if one were in fact held.

Although trial judges were thus left with discretion to do little or nothing, they were not given unlimited discretion to take whatever action they thought appropriate. One of the questions raised in discussions of the early drafts of the Rule was the extent to which trial judges could decide on their own at a pretrial conference-without an appropriate motion by one of the parties under the relevant Rule-to eliminate certain issues of law or fact from the case. Sunderland's writings seemed to contemplate that possibility, ${ }^{34}$ and an early draft of the Rule spoke of the judge's authority to issue an order "setting forth issues" and "stating that as to others no real and substantial dispute exists." But Mitchell and others on the Advisory Committee objected to the idea that the judge should be able to eliminate issues even after pro-

so See id. at 216-19.

31 Tentative Draft II of Rule 20 provided that on motion of any party or on its own initiative, the court, "after hearing the parties," might enter an order "setting forth the issues to be tried in the action" and limiting the trial to those issues, or "directing such amendment of the pleadings as will clearly and precisely set forth the real and substantial issues." FED. R. Crv. P. 20 (tent. draft II, Dec. 23, 1935) (unpublished draft available in the Harvard Law School Library and on file with the University of Pennsylvania Law Review).

${ }^{32}$ William D. Mitchell, former Attorney General of the United States.

${ }^{33}$ Chairman Mitchell said:

Oh, he may grant the order. But he must hear the proceedings. He has to sit there and hear it all, and then he may or may not grant the order. And I doubt if it is wise to force all this on all federal judges. I think it ought to be discretionary with them, as to whether they entertain it or not.

2 Proceedings of Meeting of Advisory Committee on Rules for Givil ProCedure of the Supreme Court of the United States 511 (1936) (Charles E. Clark Papers, Stirling Memorial Library, Yale University) (on file with the University of Pennsylvania Law Review) [hereinafter 1936 PRoceEdings].

34 See Sunderland, supra note 29, at 226. 
test. $^{33}$ Thus the final version of the Rule, though perhaps not resolving the question as clearly as it might have, did not contain the quoted language; it spoke only of a pretrial order "which recites the action taken at the conference, the amendments allowed . . . , and the agreements made . . . , and which limits the issues for trial to those not disposed of by agreements or admissions of counsel." The judge's authority to eliminate issues over protest was thus apparently limited to the more formal processes specified in such Rules as 12(b)(6) (motion to dismiss for failure to state a claim) and 56 (summary judgment). ${ }^{36}$ The adversary system, Clark insisted in a later discussion of the pretrial process, allows each party the privilege of presenting its case "without unnecessary judicial interference."

This reluctance of the rulemakers to allow the judge to coerce the parties was reflected even more clearly in their attitude toward settlement. Then, as now, most cases that were filed never went to trial, and most of those disposed of without trial were settled by agreement of the parties. Yet settlement was not mentioned in the Rule's description of those items appropriate for consideration at a pretrial conference. Writing some years later, Clark said that the omission was "no mere chance." 38 "Compelled settlement negotiations," he said, "are dangerous as bringing in question the impartiality of the tribunal. . ."39 Settlement, in what was probably the prevailing view at the time, might be a by-product of a well-run pretrial conference but should not

${ }^{35}$ Early in the discussion of Tentative Draft II of rule 20, supra note 31 , Chairman Mitchell said: "The judge should not be given power to exclude an issue from trial, against the protest of either party, merely because the judge thinks the evidence is too flimsy." 1936 Proceedings, supra note 33, at 507. Although Edmund Morgan then protested that the judge should have such power, the remaining discussion appeared to distinguish the contemplated pretrial conference from the proposed procedure for summary judgment and ended with George Donworth saying:

[I]f the judge simply takes the bit in his teeth and says "Oh, I don't believe there is much in that," and so on, then there will be many reversals because the party has not had his trial on the issues. . . .

However, I think that is a routine matter that will be cured in the course of experience as we pass along.

Id. at 514-15.

${ }^{36}$ Of course, one of those motions might properly be disposed of at a pretrial conference, if the provisions of the relevant rule were satisfied.

${ }_{37}$ Clark, To an Understanding Use of Pre-Trial, 29 F.R.D. 454, 456 (1962).

${ }^{38}$ Id. at 455. In the 1936 Advisory Committee discussions, George Wharton Pepper said: "I shall be for this if you can put in a provision that it will be subject to the impeachment of the court, if the court uses this opportunity to suggest a settlement, and tries to make the parties settle." 1936 ProceEdiNGs, supra note 33, at 509.

${ }^{39}$ Clark, supra note 37, at 456; see also Clark, Objectives of Pre-Trial Procedure, 17 OHı ST. L.J. 163, 167 (1956) ("Pre-trial used as a club to force settlements ... will pretty surely lead to its elimination as its potentialities for unfairness become more apparent. ..."). 
be a primary goal. ${ }^{40}$ Indeed, extensive management of the pretrial process itself, though not explicitly ruled out by the terms of the rule, did not appear to play an important part in the thinking or deliberations of the rulemakers on Rule $16 .{ }^{41}$ In general, such matters as the timing and scope of pretrial discovery were to be handled by the parties, at least in the first instance.

The picture emerges, then, of a Rule designed to substitute for formal pleadings the less formal processes of discussion and exchange as ways of narrowing issues for trial and of expediting proof. But because flexibility and discretion were the watchwords, judges were not instructed to do anything; they would only be encouraged to act. At the same time, they were not given express power to act coercively in any way not authorized by other, more formal procedures, and the comments of several important figures in the drafting of the rules left little doubt of their resistance to the coercive use of the conference.

\section{Fifty Years of EXPERIENCE}

\section{A. Forty-five Years Without an Amendment}

Most of the significant Rules promulgated in 1938, and many of the lesser ones too, were amended at least once in the first forty-five years of their existence. Yet Rule 16 remained untouched throughout that period, and was not amended until the fifth (or perhaps the sixth) major wave of amendments, in 1983. Was this because the Rule was working so well that no improvements were required, or is the explanation less idyllic?

Perhaps the answer is a little bit of each. The Rule plainly encouraged many judges to do exactly what the rulemakers hoped they would do. But it is also true that the discretion granted by the Rule was so unbounded that it was difficult to criticize any use judges made of it. Indeed, surveys taken during the period, as well as discussions by judges and commentators, reflected an extraordinary range of practices that had developed within the framework of the Rule. While in some districts judges made relatively little use of the Rule, and seldom required pretrial conferences, other districts promulgated elaborate local rules that required pretrial conferences in most or all cases and/or imposed heavy burdens on counsel to confer in advance and to prepare

to See, e.g., Sunderland, Procedure for Pretrial Conferences in the Federal Courts, 3 Wyo. L.J. 197, 202-03 (1949); Galanter, The Emergence of the Judge as a Mediator in Civil Cases, 69 Judicature 257, 258-59 (1986).

${ }^{41}$ But see Burbank, supra note 28, at 1476-77 (suggesting that Sunderland did contemplate judicial control as a means of "separating the wheat from the chaff"). 
detailed pretrial orders for the judge's consideration. ${ }^{42}$ Some judges held pretrial conferences early and often, and were encouraged to do so in complex cases by the Manual for Complex Litigation. ${ }^{43}$ Some judges saw the pretrial conference as the chance to compel the parties to produce information that had not been (and perhaps could not be) sought in routine pretrial discovery; ${ }^{44}$ others saw the occasion as an opportunity to rid the case of frivolous or insubstantial issues of fact or law, whether or not requested to do so by one of the parties in an appropriate motion; ${ }^{45}$ still others saw the conference as a device to facilitate settlement, and saw the judge as a major player in that process. ${ }^{46}$

These developments did not occur without some heckling from the sidelines. Judges Milton Pollack, Skelly Wright, and Charles Clark (having been elevated to the bench from academic status) all wrote and spoke of their concern that routine insistence on elaborate pretrial preparation and paperwork was not saving time, it was wasting it. ${ }^{47}$ Clark went on to express his apprehension that courts were reverting to the archaic bill of particulars in requiring so much detail, and that litigants were being coerced by a process that was designed to be consensual and persuasive. $^{48}$

42 For discussion of the range of local rules and practices during the period before the 1983 amendment, see, e.g., 6 C. Wright \& A. Miller, Federal Practice AND Procedure $\S 1523$ (1971) [hereinafter Federal Practice and Procedure]; Flanders, Case Management in Federal Courts: Some Controversies and Some Results, 4 Just. Sys. J. 147 (1978) (giving results of survey of court procedures); Note, Pretrial Conference: A Critical Examination of Local Rules Adopted by Federal District Courts, 64 VA. L. REv. 467 (1978) (comparing district courts).

${ }^{43}$ For discussion of the origin and recommendations of the Manual, which is published under the auspices of the United States Judicial Conference, see 6 Federal PRACTICE AND PRocedure, supra note 42, at $\S 1530$. A new edition of the Manual, published in 1985, contains less than its predecessor on the uses of the pretrial conference because amended rule 16 "contains much more guidance for the courts on case management." Id. at Supp. 1987.

44 See, e.g., Buffington v. Wood, 351 F.2d 292, 298 (3d Cir. 1965); Wirtz v. Hooper-Holmes Bureau, Inc., 327 F.2d 939, 943 (5th Cir. 1964); Berger v. Brannan, 172 F.2d 241, 243 (10th Cir. 1949), cert. denied, 337 U.S. 941 (1949).

${ }^{45}$ See, e.g., Diaz v. Schwerman Trucking Co., 709 F.2d 1371, 1375 n.6 (11th Cir. 1983) (dictum) (court could summarily dismiss case in pretrial, even absent summary judgment motion); Holcomb v. Aetna Life Ins. Co., 255 F.2d 577, 580 (10th Cir.) (same), cert. denied, 358 U.S. 879 (1958); Pifcho v. Brewer, 77 F.R.D. 356, 357 (M.D. Pa. 1977) (same).

16 For descriptions of judicial practices with respect to settlement during this period, see, e.g., Galanter, supra note 40, at 259-61; Galanter, " . . . A Settlement Judge, Not a Trial Judge:" Judicial Mediation in the United States, 12 J.L. \& Soc'y 1 (1985); Kritzer, The Judge's Role in Pretrial Case Processing: Assessing the Need for Change, 66 JudicATURE 28 (1982); Will, Merhige \& Rubin, The Role of the Judge in the Settlement Process, 75 F.R.D. 203 (1977).

47 See, e.g., Clark, supra note 37, at 458; Pollack, Pretrial Conferences, 50 F.R.D. 451, 454-63 (1971).

${ }^{48}$ See Clark, supra note 37 , at $458-61$. 
Nor did the courts of appeals give their blessing to everything the trial judges did in the name of Rule 16. They recognized, ungrudgingly, the authority of the district judges to require lawyers to attend and to prepare adequately, and to impose sanctions for failures to do so, ${ }^{49}$ as well as the constraining force of pretrial orders. ${ }^{50}$ But they balked at judges' efforts to compel the parties to engage in discovery, ${ }^{51}$ or to dispose of issues of fact or law without meeting the requirements and standards set by other rules. ${ }^{62}$ And perhaps of greatest interest, in view of the broad discretion granted by the rule, a few courts strongly criticized local practices and rules imposing onerous preparation burdens on counsel..$^{\text {s3 }}$

At a more general level, the major development during this period was a sea-change in the attitude of many, perhaps most, judges toward their role in the pretrial period-a change that occurred with surprisingly little concern for the purposes and limitations of Rule 16. Judges began to see themselves less as neutral adjudicators-deciding what the parties brought to them for decision and proceeding at a pace to be determined by the parties-and more as managers of a costly and complicated process. Many district courts began to assign judges to a case from the beginning, and many judges, encouraged by this system and by the increased availability of magistrates and other support staff, began to manage their cases with a firm hand. ${ }^{54}$ Crowded dockets, costly discovery, and delay were seen as problems not just for the litigants but for the system, and even the litigants were thought of as frequent vic-

49 See, e.g., Link v. Wabash R.R., 370 U.S. 626, 633 (1962); Transamerica Corp. v. Transamerica Bancgrowth Corp., 627 F.2d 963, 966 (9th Cir. 1980).

so See, e.g., Ely v. Reading Co., 424 F.2d 758, 762-64 (3d Cir. 1970). But cf. Clark v. Pennsylvania R.R., 328 F.2d 591, 594-95 (2d Cir.) (not an abuse of discretion to receive testimony of two witnesses whose names were not on defendant's pretrial list), cert. denied, 377 U.S. 1006 (1964); McDowall v. Orr Felt \& Blanket Co., 146 F.2d 136, 137-38 (6th Cir. 1944) (amendment of pleadings should have been allowed even though inconsistent with pretrial order). See generally Federal Practice and PROCEDURE, supra note 42 , at $\S 1527$ (courts seldom insist upon rigid adherence to statements made during pretrial conference).

51 See, e.g., Identiseal Corp. v. Positive Identification Sys., Inc., 560 F.2d 298 (7th Cir. 1977).

${ }^{62}$ See, e.g., J.F. Edwards Constr. Co. v. Anderson Safeway Guard Rail Corp., 542 F.2d 1318, 1325 (7th Cir. 1976); Syracuse Broadcasting Corp. v. Newhouse, 271 F.2d 910, 914 (2d Cir. 1959).

${ }^{33}$ See, e.g., McCargo v. Hedrick, 545 F.2d 393, 397 (4th Cir. 1976); Padovani v. Bruchhausen, 293 F.2d 546, 548-49 (2d Cir. 1961) (opinion of the court by Clark, J.).

54 The story is told in a number of places and from many perspectives. See, e.g., Elliot, Managerial Judging and the Evolution of Procedure, 53 U. CHI. L. REv. 306 (1986); Galanter, supra note 40; Kritzer, supra note 46; Peckham, The Federal Judge as a Case Manager: The New Role in Guiding a Case from Filing to Disposition, 69 CALIF. L. REv. 770 (1981); Resnik, Managerial Judges, 96 HARv. L. REv. 374 (1982). 
tims of their lawyers' self-interest. The role of the judge, then, was to keep cases moving at a reasonable pace, and to see that cases not be needlessly tried. Indeed, the concept of disposition without trial began to embrace a variety of inventive techniques other than simple mediation and settlement. ${ }^{55}$

This transformation too has had its critics, though so far they have not had much more success at holding back the tides than did King Canute. Clark's concern with the growing emphasis on settlement has already been mentioned, ${ }^{56}$ as has the occasional appellate reversal of a trial court's excessive zeal in holding the parties' feet to the fire. ${ }^{57}$ But those reversals have not dissuaded, and were not intended to dissuade, trial judges from focusing on case management and from encouraging the parties to settle in less coercive ways. Broader questioning of judges as managers, and of the efficiency and desirability of judges as mediators and facilitators, has been heard from various academic encampments, ${ }^{58}$ so far without much noticeable impact, except perhaps on other academics.

\section{B. The 1983 Amendment: Riding the Back of the Tiger}

The 1983 amendment of Rule 16, like many amendments of other Rules over the years, ${ }^{59}$ made the text a good deal longer. ${ }^{60}$ Though this was not an avowed purpose of the change, the increase in length surely was an implicit adoption of the view of the rulemakers that the content of a rule affects what judges do; otherwise, why bother with so many words?

The purposes of the amended Rule have been described in the Ad-

so For example, the use of summary jury trial and minitrial. For a full description of these and other techniques, see D. Provine, Settlement Strategies for FedERAL DISTRICT JUDGES (1986), and especially Chapter IV. The debate over the desirability of these alternative procedures has been a lively one. Compare, e.g., Lambros, The Summary Jury Trial-An Alternative Method of Resolving Disputes, 69 JuDICATURE 286 (1986) with, e.g., Posner, The Summary Jury Trial and Other Methods of Alternative Dispute Resolution: Some Cautionary Observations, 53 U. CHI. L. Rev. 366 (1986).

${ }^{6 B}$ See supra text accompanying notes $38-39,47-48$.

${ }^{57}$ See supra text accompanying notes 51-53.

s8 See, e.g., Galanter, supra note 40; Galanter, supra note 46; Landsman, The Decline of the Adversary System: How the Rhetoric of Swift and Certain Justice Has Affected Adjudication in American Courts, 29 Buffalo L. Rev. 487 (1980); Resnik, supra note 54.

${ }_{59}$ For some striking examples, see FED. R. Crv. P. 15(c) (expanded in 1963 from 45 to over 200 words); FED. R. Crv. P. 23 (expanded in 1966 from some 400 words to some 1000 words, plus spin-off rules 23.1 and 23.2 totaling some 300 words); FED. R. Crv. P. 50 (addition of two new subsections, totaling some 300 words, in 1963).

${ }^{60}$ For the text of the original and amended Rule, see supra note 2. 
visory Committee's Note and in comments by its Reporter, Arthur Miller. ${ }^{61}$ A major purpose was to recognize, and indeed to embrace, the strong trend toward increased judicial management of litigation from an early stage of the lawsuit. Among the means of expressing this purpose were the authorization of an early scheduling conference at which various deadlines would be established and further conferences agreed upon, and the inclusion among the subjects to be discussed of a number of matters relating not to the trial itself but to the pretrial period. ${ }^{62}$

Several aspects of this move toward increased judicial control are worth noting. First, with one exception, the tradition of discretion-of authorizing a range of actions but not requiring them-is continued. Today's rulemakers believe, as did their predecessors, in the value of flexibility as a means of promoting the fair and just disposition of cases. The sole exception is that the amended Rule mandates a scheduling order not more than 120 days after filing of the complaint, an order that must be based on consultation with the parties, that must include deadlines for joinder and amendment, for the filing and hearing of motions, and for the completion of discovery, and that may include certain other items. The mandate itself contains an escape valve; it does not apply to "categories of actions exempted by district court rule as inappropriate." But note that the escape is only by category, not through the exercise of ad hoc discretion by individual district judges. Note also that the deadline for amendment seems to run squarely counter to the provision of rule 15(a) that "leave [to amend] shall be freely given when justice so requires." the ground that justice prefers enforcing a deadline when one has been set in a scheduling order.

Second, the amended Rule specifically includes among the "Subjects to be Discussed" at pretrial conference (in addition to "admissions" and "stipulations") "the elimination of frivolous claims and defenses." ${ }^{\text {"64 }}$ Although the language is far from clear about whether judges may do more than "discuss" this matter if the parties are unwilling to agree, and if so, whether the Rule gives them authority to do more than they can already do under such provisions as Rules $12(\mathrm{~b})(6)$ and 56 ,

61 The Advisory Committee's Note may be found in 90 F.R.D. 470 (1981). For comments by the Reporter, see Miller \& Culp, The New Rules of Civil Procedure: Managing Cases, Limiting Discovery, 6 NAT'L L.J., Dec. 5, 1983, at 23.

${ }_{62}$ See FED. R. Civ. P. 16(a)(1)-(3), (5), (b), (c)(7), (9)-(10). The amended Rule, unlike its predecessor, speaks of "pretrial conferences," and the title of the rule also refers to "scheduling" and "management."

${ }^{63}$ FED. R. CIV. P. 15(a).

64 FED. R. GIv. P. 16(c)(1); see also FED. R. CIv. P. 16(c)(3) (obtaining admissions to avoid "unnecessary proof"). 
the very inclusion of the phrase suggests a departure from the original emphasis on consent, and from the view of Mitchell and Clark that coercion at the pretrial conference was out of place. ${ }^{65}$

A further purpose of the amendment, overlapping the first, is to embrace another trend: the increased involvement of the trial judge in the settlement process. Among the stated objectives of a pretrial conference, there appears in Rule 16(c)(7) "the possibility of settlement or the use of extrajudicial procedures to resolve the dispute." By authorizing this initiative, the amendment implicitly rejects the views of some observers that judicial involvement in settlement is inconsistent with the judge's role as neutral adjudicator and may produce neither more settlements, nor settlements of better quality, than would result if judges stayed out of the process. ${ }^{66}$ Yet the amendment is silent on such impor-

6s See supra notes 35-37 and accompanying text. The Advisory Committee's Note to the amendment states that the reference to "formulation" in rule $16(c)(1)$ is intended to confirm the court's power to "identify" the litigable issues. (The case cited at this point, Meadow Gold Products Co. v. Wright, 278 F.2d 867, 869 (D.C. Cir. 1960), merely stated, in dictum, that in view of the simplicity of federal pleading, pretrial procedure had become "the principal means of defining the issues . . . and the legal theories.") The Note then goes on to say that the notion of identifying the issues:

is emphasized by expressly authorizing the elimination of frivolous claims or defenses at a pretrial conference. There is no reason to require that this await a formal motion for summary judgment. Nor is there any reason for the court to wait for the parties to initiate the process called for in Rule $16(\mathrm{c})(1)$.

Note, supra note 61 , at 474 .

Troublesome stuff, at least for me, but that is for another paper.

${ }_{68}$ The literature on settlement, and on the desirability of judicial involvement, is large and growing. For a general discussion and bibliography, see ALI STUDY, supra note 21 , at 90-97, A25-A28.

For material casting some doubt on the assumptions underlying Rule 16(c)(7), see, e.g., S. Flanders, Case Management and Court Management in the United States Courts 37-39 (1977) (questioning the value of "a large expenditure of judicial time" on settlement); M. Rosenberg, The Pretrial Conference and EfFecTIVE Justice 46 (1964) (empirical study of pretrial conferences in New Jersey state courts indicates that compulsory pretrial conferences do not increase the frequency of settlement); Church, Civil Case Delay in State Trial Courts, 4 Just. Sys. J. 166, 189 (1979) (concluding from a study of state trial courts that "extensive court involvement in settlement activity is non-productive"); Fiss, Against Settlement, 93 YALE L.J. 1073, 1075 (1984) (arguing that settlement is not preferable to judgment on the merits and "should be neither encouraged nor praised"); Galanter, supra note 40, at 262 (raising questions as to whether judicial involvement increases either the quantity or quality of settlement); Resnik, supra note 54, at 414-31 (criticizing judicial involvement); Galanter, The Quality of Settlements (unpublished draft 1988) (on file with the University of Pennsylvania Law Review) (raising broader questions about the relative value of settlement and adjudication); of. Fuller, Collective Bargaining and the Arbitrator, 1963 Wrs. L. REv. 1, 18-27 (arguing that persons serving as labor arbitrators should not simultaneously attempt to engage in mediation). But cf. Stevenson, Watson \& Weissman, The Impact of Pretrial Conferences: An Interim Report on the Ontario Pretrial Conference Experiment, 15 Osgoode HaL. L.J. 591 (1977) (reporting on an experiment indicating that judicial involvement in pretrial settlement conferences both 
tant questions as the approaches that may be used; the extent to which the trial judge may require the parties to talk about settlement, or act in good faith, or resort to particular procedures; or when and whether a judge's participation in settlement should disqualify him from continuing to preside over other aspects of the case.

A final purpose of the amendment, again essentially an endorsement of what many judges were already doing, is reflected in the inclusion in the rule itself of a provision for sanctions against parties and attorneys who violate orders or who fail to participate at all or with sufficient enthusiasm in a pretrial conference. Like most of the other provisions of the rule, the language is discretionary, except that the judge "shall" require the noncomplying party or attorney to pay the reasonable expenses incurred because of noncompliance unless there is a finding that the noncompliance was substantially justified or that an award would be unjust.

This specific authorization of sanctions was part of a broader move in the 1983 amendments to make parties and their attorneys answerable to the court, and to their adversaries, for the filing of papers or other actions or inactions thought to be responsible for the heavy costs and delays of litigation in the federal courts. ${ }^{67}$

\section{Since the Amendment}

The amendment became effective on August 1, 1983, and so we have about six years of experience under the new Rule. That is not a long time as these things go; it takes a while for developments to come to the attention of commentators and appellate courts. But since Rule 16 is closely related to the major change in thinking about the judicial role, some interesting questions have been raised, and the last year or so has seen some important appellate decisions.

One study, completed in the year following the amendment, reported that a considerable number of districts had already promulgated local rules exempting certain categories of cases from the provision for a mandatory scheduling order. ${ }^{68}$ The districts, as expected, did not coincide in their choices-Alaska exempted cases where "travel by the

increased the settlement rate and effected an overall saving of judicial time).

${ }^{67}$ Other Rules amended in 1983 to include specific provisions for sanctions are

FED. R. GIV. P. 11, 26. See generally Burbank, Sanctions in the Proposed Amendments to the Federal Rules of Civil Procedure: Some Questions About Power, 11 HoFSTRA L. REv. 997, 1006 (1983) (raising questions about the validity of these provisions, especially to the extent that they purport to require judicial action).

${ }_{68}$ See N. Weeks, District Court Implementation of AMENded Federal Givil Rule 16: A Report on New Local Rules 17 (1984). 
Court" within 120 days is not feasible, ${ }^{69}$ and the District of Columbia exempted actions under the Freedom of Information $\mathrm{Act}^{\mathrm{70}}$-but there was considerable overlap. ${ }^{71}$ Districts varied in the detail of their new rules, and a few added a catchall category of cases that were to be exempted if, in the words of one rule, "the burden of a scheduling order would exceed the administrative efficiencies to be gained."72

What has been happening with this new mandatory requirement? Have the district judges been conscientiously issuing scheduling orders, within the time required by the rule, in all cases not categorically exempted? Have they been hard on requests for extensions of deadlines already set? Had I world enough and time, I would have attempted to obtain systematic empirical answers to these questions for use in this symposium, and I hope that someone more zealous than I will try to get them. As it is, I must rely on a combination of some informal discussions with a few federal judges, and of intuition about how rules like this tend to operate, at least in their early stages. My guess is that most judges are conscientious about compliance but that many are not, that many find it difficult if not impossible to do all that is required within 120 days, that many are coming to rely on boilerplate provisions for routine cases, ${ }^{73}$ that a substantial number are fairly relaxed about granting extensions of deadlines set in the original order, and that a majority are unhappy about having to consult with the parties and issue a scheduling order in every nonexempt case.

Outside the realm of scheduling orders, and in other spheres of judicial management, the elaboration of judicial authority in the amended rule does not seem to have resulted in increased certainty about what judges may properly do. Perhaps this continuing doubt can be explained, at least in part, by the human tendency to push against even the broadest limits. In any event, I suspect it will be quite a while

69 See id. app. B (reprinting United States District Court for the District of Alaska, Local Rule (9)(c)(xi)).

${ }^{70}$ See id. (reprinting United States District Court for the District of Columbia, Local Rule 1-15(e)(1)).

71 Cases commonly exempted include prisoner petitions, collection cases brought by the United States, suits to quash or enforce subpoenas, and proceedings in bankruptcy. See id.

72 See id. (reprinting United States District Court for the District of Alaska, Local Rule 9(C)(xii)); see also id. at 9 (referring to other districts with similar provisions).

${ }_{73}$ Among the variations in local rules discussed by Weeks are two (the Middle District of Alabama and the Western District of Washington) that establish "fixed-date scheduling orders rather than case-specific ones." Id. at 11.

Several judges told me that they rely heavily on magistrates to consult with the parties and to issue scheduling orders. The magistrates in the busier federal districts are, like the judges, overworked. 
before the questions now being raised are resolved, and their resolution will undoubtedly lead to new questions no one has yet thought about.

Most of the questions revolve around judicial efforts to test the limits of what appears to be an even broader discretion to manage litigation. Thus one issue is whether the amended Rule gives the district judge more power than before to dispose of issues, or the whole case, over the resistance of one of the parties. One circuit, which has confronted the question head-on in two cases, has answered with a firm "no." "74

A newer set of issues relates to the authority of judges to nudge, or shove, the parties toward settlement. Reported district and appellate court cases are, of course, only the tip of the iceberg, and stories told by lawyers, judges, and their observers would curl the hair of those who continue to see the judge as primarily a detached neutral adjudicator. ${ }^{75}$ But some juicy cases may be found in the reports too. Thus one district judge said to counsel that he was going to hold a conference to discuss settlement and instructed one of the lawyers to " $\mathrm{t}$ ] $\mathrm{ell}$ them [the insurance company client] not to send some flunky who has no authority to negotiate. I want someone who can enter into a settlement in this range without having to call anyone else." "76 The client declined the invitation, and the judge struck the defendant's pleadings but allowed the insurance company to "purge itself of contempt" by writing a letter of public apology. This question-whether a judge can require that someone with authority to settle a case appear at a pretrial conference-has troubled the appellate courts. ${ }^{77} \mathrm{I}$ for one find it hard to read this au-

74 See Williams v. Georgia Dep't of Human Resources, 789 F.2d 881, 883 (11th Cir. 1986); Fidelity \& Deposit Co. v. Southern Utils., Inc., 726 F.2d 692 (11th Cir. 1984). In Fidelity, the district court had acted prior to the adoption of the 1983 amendment to Rule 16, see 555 F. Supp. 206 (M.D. Ga. 1983), but the Eleventh Circuit's reversal occurred after the amendment, and was relied on two years later in Williams. But cf. Portsmouth Square, Inc. v. Shareholders Protection Comm., 770 F.2d 866, 86870 (9th Cir. 1985) (upholding trial judge's sua sponte dismissal, without prior notice, at pretrial conference).

${ }^{75}$ For an exhaustive but gripping account of one extraordinary instance of judicial involvement, see P. Schuck, Agent Orange on Trial (1986). The Agent Orange litigation was, of course, a class action, and class action settlements are subject to judicial approval, see FED. R. CIV. P. 23(e). But that requirement, in my view, only compounds the difficulty of judicial involvement in negotiating the terms of the settlement.

${ }^{76}$ Lockhart v. Patel, 115 F.R.D. 44, 45 (E.D. Ky. 1987).

77 See In re LaMarre, 494 F.2d 753, 756-58 (6th Cir. 1974) (holding, prior to the 1983 amendment, that attendance of a person with authority to settle could be required, but reversing a criminal contempt fine for lack of a sufficiently clear order or command); G. Heileman Brewing Co. v. Joseph Oat Corp., 848 F.2d 1415, 1420 (7th Cir. 1988) (holding, under the amended rule, that the power to compel such an appearance does not exist), rev'd, 871 F.2d 648 (7th Cir. 1989) (en banc). 
thority into Rule $16,{ }^{78}$ and am concerned that many clients who are not themselves skillful negotiators may suffer if their presence at such a conference can be compelled.

A related question is whether and to what extent a trial judge may impose sanctions for a party's failure to act "reasonably" or "in good faith" in the settlement process. In Kothe v. Smith, ${ }^{79}$ the plaintiff had demanded $\$ 50,000$ before trial and defendant had offered $\$ 5,000$; the judge had recommended a settlement of $\$ 20-30,000$. Plaintiff's attorney had disclosed to the judge (but not to the defendant) that his client would be willing to settle for $\$ 20,000$. After one day of trial, the case was in fact settled for $\$ 20,000$, and the trial judge ordered defendant to pay a total of $\$ 2,480$ ( $\$ 1,000$ to plaintiff's attorney, $\$ 1,000$ to plaintiff's medical witness, and $\$ 480$ to the clerk of the court) for the unreasonable delay in coming to terms. The Second Circuit reversed, holding the action an abuse of the authority conferred by Rule 16(f). It noted that the court had imposed the sanction on only one side and that negotiation is a two-way street, thus raising the question whether the trial judge would have fared better by fining both sides.

In Hess v. New Jersey Transit Rail Operations, ${ }^{80}$ the trial judge tried a different tack. He ordered the defendant to make a "bonafide" pretrial settlement offer, but in the face of a $\$ 150,000$ demand by the plaintiff, no offer was made. On the third day of trial, following a reduced demand (for $\$ 110,000$ ) by the plaintiff, the case was settled for $\$ 85,000$. The trial judge imposed a fine of $\$ 1,000$ on the defendant, noting that it had behaved with similar obstreperousness in the past and saying "maybe [now] the point will get across."81 The Second Circuit reversed, holding the case substantially governed by Kothe and also noting that a requirement of a "bonafide" offer was too vague to support a conviction for criminal contempt.

The courts of appeals are not, however, in harmony on this question. In Eash v. Riggins Trucking Inc. ${ }^{82}$ a case was settled on the first

78 The Rule, in subdivision (a), authorizes the court to "direct the attorneys for the parties and any unrepresented parties to appear before it for a conference," and in subdivision (c) explicitly states that "[a]t least one of the attorneys for each party participating in any conference before trial shall have authority to enter into stipulations and to make admissions." In view of the reference in subdivision (c)(7) to "the possibility of settlement" as one of the discussable subjects, the absence of any specific grant of the kind of authority claimed in LaMarre does not seem inadvertent. I recognize, of course, that the canon "expressio unius" is often honored in the breach, but this seems a strong case for applying it in view of the delicacy of the issue.

78771 F.2d 667 (2d Cir. 1985).

80846 F.2d 114 (2d Cir. 1988).

81 Id. at 115.

82757 F.2d 557 (3d Cir. 1985) (en banc); see also White v. Raymark Indus., 783 F.2d 1175, 1176-78 (4th Cir. 1986) (upholding imposition of costs as a sanction for 
day of trial, and the trial judge, concluding that the defendant had failed to bargain adequately about settlement before the trial, imposed a fine of $\$ 390$ (the per diem charge for 13 jurors). A divided Third Circuit, sitting en banc, held that the judge had inherent authority to impose the sanction, but reversed because the defendant had not been given adequate notice and opportunity to be heard. Three dissenters termed the judge's actions "unprecedented judicial activism" and noted that the sanction fell outside those authorized either by the 1983 amendments to the Rules or by the criminal contempt statute. ${ }^{\mathbf{8 3}}$

Finally, the lines have yet to be drawn with respect to a trial judge's authority to impose new techniques for avoiding full-scale trial on an unwilling litigant. So far, at least one appellate court, the Seventh Circuit, has denied the power of a trial judge to compel the holding of a nonbinding "summary jury trial," saying that neither the court's inherent authority nor the provisions of Rule 16(c)(7) and (11) allowed the court to force any form of settlement negotiations on an unwilling litigant. ${ }^{84}$ But other courts, both before and since the Seventh Circuit decision, have emphatically disagreed. ${ }^{85}$

\section{INFERENCES AND OBSERVATIONS}

What light does this story shed on the questions raised at the outset of this paper? Does it tell us anything about the realizability of the goals of the original rulemakers, or about the desirability and consistency of those goals at least under current conditions? I think it does, but subject to a few caveats. First, similar study of other Rules would

"unjustified delay" in settling).

${ }_{83}$ See Eash, 757 F.2d at 573, 574-81 (Sloviter, J., joined by Gibbons and Higginbotham, JJ., dissenting).

${ }_{84}$ See Strandell v. Jackson County, Ill., 838 F.2d 884, 886-88 (7th Cir. 1987). The plaintiff's counsel in this case had refused to participate in a summary jury trial, claiming that protected work product might have to be disclosed in the course of the proceeding. See id. at 884-85. The trial court held plaintiff's counsel in contempt, and the court of appeals reversed. See id. at $885,888$.

${ }^{85}$ See, e.g., McKay v. Ashland Oil, Inc. 120 F.R.D. 43, 46-48 (E.D. Ky. 1988) (mandatory summary jury trial is within the power of the court); Arabian Am. Oil Co. v. Scarfone, 119 F.R.D. 448, 449 (M.D. Fla. 1988) (upholding the court's power to require participation in a nonbinding summary jury trial); Kimbrough v. Holiday Inn, 478 F. Supp. 566, 572-74 (E.D. Pa. 1979) (upholding an "experimental rule" providing for compulsory, nonbinding arbitration as a prerequisite to obtaining a jury trial). With respect to the experiment referred to in the Kimbrough case, see P. EBENER \& D. Betancourt, Court Annexed Arbitration: The National Picture (1985); Nejelski \& Zeldin, Court-Annexed Arbitration in the Federal Courts: The Philadelphia Story, $42 \mathrm{MD}$. L. REv. 787 (1983); see also Judicial Improvements and Access to Justice Act, Pub. L. No. 100-702, §§ 901-907, 102 Stat. 4642, 4659-64 (1988) (to be codified at 28 U.S.C.) (authorizing, for a period of five years, the use of nonbinding arbitration procedures in certain cases in certain federal districts). 
at least lend a further dimension to the discussion and might cast considerable doubt on any inferences drawn from the history of this Rule alone. Second, even the study of Rule 16 has been essentially anecdotal, and could benefit from more systematic investigation of what has happened and is happening. Finally, I suspect that I share the general human failing of seeing in the data (perhaps too scientific a word in this context) what I thought was likely to be there before I started.

It is not my purpose here to take sides in the ongoing controversy about the proper limits of managerial judging. I do have views on that debate, and some may well sneak into the discussion, but they lie at the margin of my inquiry.

With that introduction, I offer five points for consideration.

1. The history of Rule 16 lends some support to the view of the skeptics that the content of rules doesn't matter, or at least that it doesn't matter much. After all, the sea-change in attitudes toward managerial judging and the judicial role in settlement took place under the rubric of a rule whose language remained unchanged until the metamorphosis was virtually a fait accompli. Indeed, Charles Clark himself had to protest that at least some of the assumptions and purposes of the rulemakers were not being adhered to. ${ }^{86}$ At best, the argument might run, the task of rulemakers is like the task of those who lay out the walks in the Cambridge Common: Figure out where people go and cover up the grass with cement on those routes. ${ }^{87}$

But the story is really more complex. Flexibility and discretion were major themes of the rulemakers, and thus they should not have been surprised that many judges used that flexibility to implement ideas the rulemakers did not wholly share. Besides, the rulemakers were not averse to reasonable efforts by judges to obtain information or to control the pace of pretrial litigation; they simply did not focus on these matters in their collective deliberations on Rule 16. In any event, the content of Rule 16 has made a difference, not only in encouraging judges to use relatively informal and consensual processes to improve the efficiency and quality of trials, but in setting perceptible limits to the ability of judges to impose requirements or to knock unwilling heads together. ${ }^{88}$

The evolution of Rule 16 is a story repeated in the evolution of many rules of open-textured quality. The framers have a general idea

s6 See supra notes 47-48 and accompanying text.

${ }^{87}$ I remember that Lon Fuller once explained how the cement walks in the Cambridge Common came to be laid out as they were, but I am unable to find the reference. Perhaps he never wrote it down.

88 See supra text accompanying notes 50-53. 
of what they want to achieve, and adoption of the rule is followed by some developments that constitute just what was intended, by some that raise questions not focused on by the framers but that they would happily have accepted (or would be likely to accept if they were able to reflect on current conditions), and by some that might well horrify them no matter how cognizant they were of contextual change.

2. At the outset of this paper, I expressed doubt that the rulemakers' desire for flexibility could be reconciled with their desire for uniformity either from judge to judge or from case to case. The point can perhaps be expressed by the following diagram, on which the vertical axis goes from wholly ad hoc (or category-specific) procedure ${ }^{88}$ to wholly uniform procedure, and on which the horizontal axis goes from no discretion to broad discretion:

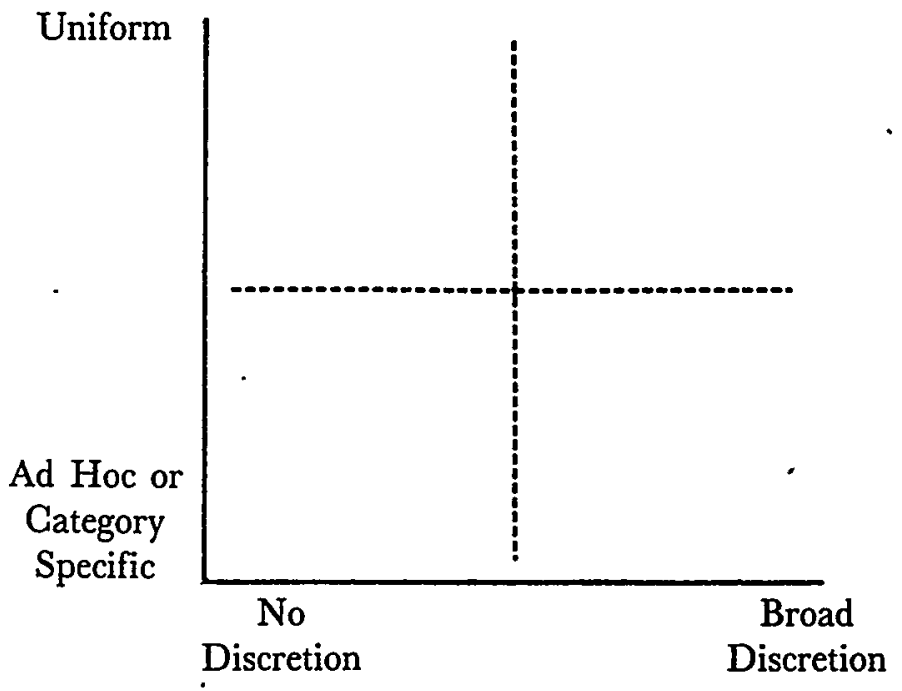

If the rulemakers wanted to create a procedural system falling in the northeast quadrant, the history of rule 16 suggests that, as a practi

89 If the universe of cases were divided into only a few categories, one would not be at the bottom of the vertical axis. The creation of many categories, though it would mean a sacrifice of case-to-case uniformity, might lead to more uniform treatment of cases within each category. Thus the diagram should perhaps be thought of as containing two superimposed vertical axes - one dealing with uniformity from judge to judge and the other dealing with uniformity from case to case. 
cal matter, the quadrant, or most of it, does not exist. ${ }^{90}$ If judges are given broad discretion, and district courts may vary widely in the local rules and standing orders they adopt, one should not expect any significant degree of uniformity from judge to judge, court to court, or case to case. True, there is a uniform rule to the effect that judges have discretion to make certain decisions, but in the words of one observer, a rule granting broad discretion is "trans-substantive [one aspect of the uniformity I have in mind] in only the most trivial sense."91

I do not mean to suggest that the goals of uniformity and flexibility are not both worthy of pursuit. But I do believe that, to a significant extent, one may be purchased only in exchange for some sacrifice of the other. ${ }^{92}$

3. The history of Rule 16, I believe, suggests both the inevitability and the desirability of significant discretion in areas such as pretrial management - that the optimal stopping point on the diagram is a good deal east of the starting point. ${ }^{\text {93 }}$ As to inevitability, the point may be illustrated by the provision for sanctions in subdivision (f) of the amended Rule. Phrases like "substantially unprepared," "substantially justified," and "unjust" have enough give in them that judges will inevitably have a significant range of choice in deciding on their application, and those choices will infrequently be upset on appeal. ${ }^{94}$ The use of such phrases manages to undercut the force of the "shall" that appears in Rule 16(f), and indeed it is not clear exactly what the force of that word is. Does it mean that a judge must impose the sanction of expenses even when the adversary does not request it? Clearly a judge may impose that sanction, but several judges have told me that they ordinarily do not, and do not think the Rule obligates them to do so.

80 To the extent one goes down the vertical scale not by creating many categories but by authorizing ad hoc determinations, much of the southwest quadrant does not exist either.

91 Burbank, supra note 28, at 1474 .

82 For an argument that with the help of the law schools and other means of judicial education, uniformity and discretion are not such strange bedfellows after all, see Weinstein, After Fifty Years of he Federal Rules of Civil Procedure: Are the Barriers to Justice Being Raised?, 137 U. PA. L. REv. 1901, 1911-12 (1989).

${ }_{93}$ I have worried and written about the appropriate scope and limits of discretion on several earlier occasions. See, e.g., Shapiro, Jurisdiction and Discretion, 60 N.Y.U. L. REv. 543, 574-89 (1985); Shapiro, Some Thoughts on Intervention Before Courts, Agencies, and Arbitrators, 81 HARv. L. REv. 721, 757-63 (1968) [hereinafter Shapiro, Some Thoughts]; Shapiro, The Choice of Rulemaking or Adjudication in the Development of Administrative Policy, 78 HARv. L. Rev. 921, 972 (1965). For an effort to define the term, and to distinguish between "normative" and "allocative" discretion-between discretion delegated by a legislative body to an adjudicative body and discretion allocated within an adjudicative hierarchy-see Shapiro, Some Thoughts, supra at 546.

94 For the full text of the subdivision, see supra note 2 . 
On the question of desirability, my reading of the cases and commentary on the Rule, and my discussions with lawyers and judges, persuade me that the rulemakers were right in believing that significant discretion should be delegated-that the frequent use of "may" was a wise decision. This is so not only because the Rule was an innovative one, but because cases do vary in ways that are difficult to spell out in advance, because judges vary in their ability and willingness to make effective use of such techniques, and because "local legal cultures" vary in their receptiveness to certain techniques and practices. And some of the variations are due to differences in conditions. The District of Vermont really is different from the Southern District of New York.

Although the returns are not yet in-at least I do not have them-the one effort in the amended Rule to put a serious crimp in discretion may have been a mistake. The requirement of early scheduling discussions (by conference or otherwise) and of a scheduling order may well be costing more judicial and litigant time than it saves in relatively simple cases that do not fit one of the "exempt" categories recognized in the district; and some cases that do fall into an exempt category may warrant a scheduling order but may go unnoticed because judges are too busy with nonexempt cases. ${ }^{85}$ The efforts of a few districts to flout the mandate of the Rule by including as an exempt "category" cases in which a scheduling order is not warranted ${ }^{96}$ suggest, once again, that discretion has at least nine lives.

4. Discretion can be quite dangerous, however, when it is unbounded. Judges are human and humans tend to abuse power when they have it; Rule 16 is surely no exception. ${ }^{97}$ Should judges then be given no guidance on when pretrial conferences should be held, on what settlement techniques are out of bounds, or on whether the trial judge should participate in the settlement process, and if so, how? If unbounded discretion made sense at the outset, have we seen enough and debated enough by now to think about some limits?

I think we have. Yet, hard and fast requirements or prohibitions, as already suggested, have their own perils and should be held in reserve for extreme situations, or situations in which it is clearly more important that a matter be settled than that it be settled right. ${ }^{98}$ In

95 At least this is the view of one judge, who spoke to me quite forcefully on the subject.

98 See supra note 72 and accompanying text.

97 See, e.g., the discussion of the Kothe and Hess cases, supra notes 79-81 and accompanying text.

${ }^{88}$ The classic example is whether traffic should drive on the right side of the road or on the left, although some countries have spent a fortune in recent years to switch from one side to the other. 
many situations, I believe, "principles of preference"-rebuttable presumptions about what should be done-can go a long way toward confining discretion so that both the judge's own conscience and appellate review can effectively contain it. ${ }^{99}$

Two examples may be helpful. First, there has been a continuing debate about whether a judge who is involved in settlement discussions should preside at the trial, or at any adjudication of an issue on the merits-at least in the absence of full and informed consent by the parties. ${ }^{100}$ Among the factors that seem important are the identity of the trier of fact (the judge or a jury), the nature of the judge's participation in settlement, the nature of the case and the quality of representation, and the willingness of the parties to waive any objection. Is there perhaps a sufficient consensus by now to state some sort of principle-say that in the absence of informed consent by the parties, a judge who has become significantly involved in settlement discussions should not ordinarily preside over the adjudication of issues on the merits? Might that not be preferable to a flat prohibition or authorization, with all its potential for evasion and the exercise of hidden discretion, as well as its occasional blindness to the needs of a particular situation?

As another example, would Rule 16 serve the courts and the public better if, in addition to (in lieu of?) allowing exemption by category from the requirement of a scheduling order, the Rule incorporated the effort by some districts to allow judges to exempt on an ad hoc basis? I suspect that a great deal of time and expense might be saved if a judge could glance quickly at a file and decide that the case did not merit a scheduling order. Concern that judges might take the easy way out and exempt every case might be allayed by keeping statistics for each judge on the number and type of nonexempt cases in which scheduling orders were not issued. Such statistics, especially if expanded to report on other aspects of the scheduling process, would have independent value to the courts and to students of judicial administration. And if it turned out that the Rule was not working well, the principle of preference could be further refined.

5. If there are to be principles of preference, as well as occasional outright prohibitions and requirements, where should they fall on the vertical scale of my diagram? Should they be case specific, at least by

${ }^{99}$ See Friendly, Indiscretion About Discretion, 31 EmoRy L.J. 747, 768 (1982); Shapiro, Some Thoughts, supra note 93, at 546-47, 575.

${ }^{100}$ For discussions of the question, see, e.g., Resnik, supra note 54, at 426-31, 433-35; Will, Merhige \& Rubin, supra note 46, at 211, 224-26; cf. Fuller, supra note 66, at 18-27 (identifying the conflicts and hazards encountered when a labor arbitrator undertakes the task of mediation). 
categories of cases, or should they cut across case lines as much as possible? Where, in other words, should the principle of preference fall on the scale of uniformity?

This question may be the hardest of all on which to draw any helpful lesson from the history of the Rule-in part because the broad discretion vested by the Rule has made the question largely moot. Further information on the success of categorical exemptions from the requirement of a scheduling order may be useful, but I suspect that it will not give any firm guidance.

$\mathrm{My}$ own view is that specific categories are likely to be especially troublesome when the consequences of falling into a category are mandated by the Rule. Suppose, for example, that the Rule provided that a pretrial conference must be held at an early stage whenever a case falls into a particular category. Wouldn't we be running a serious risk (a) that time would be wasted arguing about proper categorization, (b) that a number of cases falling into that category would not profit from an early conference, and (c) that cases not falling into the category might be slighted even though particular ones might profit from an early conference? Wouldn't there be a net gain from a more flexible principle of preference that pretrial conferences should normally be held at an early stage in certain kinds of cases? ${ }^{101}$ True, there may well be controversies about the application of that principle, but such controversies are more likely to be germane and productive, especially if the principle itself does not suggest the drawing of arbitrary distinctions among different kinds of cases. Moreover, the existence of a significant degree of flexibility and generality may have the added advantage of mitigating the danger that the Rule will affect substantive rights or interfere with substantive policy objectives. ${ }^{102}$

I recognize that I am entering into the endless debate about rules and standards. ${ }^{103}$ I recognize too that a decision about whether to adopt

101 A "tracking system" that designated cases for certain kinds of treatment shortly after filing would be consistent with this suggestion if the makeup of each track were not based on "bright line" criteria like subject matter or amount in controversy but rather afforded room for discretionary judgments and contemplated adjustments worked out by the parties and the court.

${ }^{102}$ Cf. Burbank, supra note 67, at 1006-11 (arguing that the provisions for sanctions in the 1983 amendments to the Rules raise especially difficult questions under the Enabling Act in those instances where the provisions purport to eliminate or substantially constrain judicial discretion); Cover, supra note 21, at 737 (suggesting that procedural rules are appropriate for settling what is "presumptively" or "generally" available, but not for establishing categories to which substantive policies must bend).

${ }^{103}$ I wish there were a bibliography on this debate that I could cite, but I know of none. Two interesting examples of the wealth of literature, which come at the problem from very different perspectives, are Bok, Section 7 of Clayton Act and the Merging of Law and Economics, 74 HARv. L. REv. 226 (1960), especially at 347-55, and Ken- 
a hard-and-fast rule always involves a trade off between the advantages of simplicity, predictability, and ease of administration, on the one hand, and the dangers of under- and over-inclusion on the other. But I am confining myself to one small corner of that debate: its relevance to the role of procedural rules in instructing, or guiding, a judge in the management of a lawsuit. Such rules do not themselves determine (though they may affect) rights and liabilities of people in their everyday affairs, and thus predictability in gross seems less important than the proper fit between the action taken and the needs of the case.

In working out an appropriate point of departure on my diagram, I see that I have positioned myself somewhere in the middle region, well away from the two coasts and from the northern and southern frontiers. Indeed, I have suggested that some of these outer positions are not available as a practical matter. But as one who prides himself on a strain of centrism and pragmatism, I am not too surprised. 